\title{
Islamic Boarding School-Based Madrasah: Policy Efforts to Reform the Superior Education Model
}

\author{
*Yeyen Afista ${ }^{1}$, M Yunus Abu Bakar ${ }^{2}$ \\ ${ }^{1}$ Universitas Hasyim Asy'ari, Jl. Irian Jaya No.55, Jombang, Indonesia \\ ${ }^{2}$ Universitas Islam Negeri (UIN) Sunan Ampel, Jl. Ahmad Yani, Surabaya, Indonesia \\ *yeynafista224@gmail.com
}

\begin{abstract}
Madrasah is an alternative educational institution and has the same opportunity to become an educational institution taken into account in social change dynamics. However, as a logical consequence, madrasas must develop each sector to achieve its organizational goals. This study examines the opportunities and challenges of developing madrasas, particularly those based on an Islamic boarding school. This study is a literature study, so that the method of analyzing data is by reviewing and collecting information from various references, both books and scientific articles, which are used as a material in studying and adding conceptual insights related to the opportunities and challenges of developing Islamic boarding school-based madrasas in the modern era. The literature review results show that in developing the education system into a preeminent institution and maintaining its existence, madrasas in Islamic boarding school are required to be open and accommodate the community's aspirations and demands. Madrasah needs to develop themselves to become high quality and superior madrasas and a bridge that connects with the national education system, especially those related to students' moral and personality development. This is understandable because the community hopes that educational institutions in Islamic boarding school are religious experts, have morals, and have future skills.
\end{abstract}

Madrasah merupakan salah satu lembaga pendidikan alternatif dan mempunyai kesempatan yang sama untuk menjadi lembaga pendidikan yang diperhitungkan dalam dinamika perubahan sosial. Namun demikian sebagai sebuah konsekuensi logis, madrasah harus melakukan upaya-upaya agar mampu mengembangakan setiap sektor dalam rangka mewujudkan tujuan organisasinya. Studi ini bertujuan untuk mengkaji peluang dan tantangan pengembangan madrasah, khususnya yang berbasis Islamic boarding school. Studi ini merupakan studi literatur sehingga metode dalam menganalisis data dengan meninjau dan mengumpulkan informasi dari berbagai referensi baik buku, artikel ilmiah yang digunakan sebagai bahan dalam mempelajari dan menambah wawasan secara konseptual yang berhubungan dengan peluang dan tantangan pengembangan madrasah yang berbasis Islamic boarding school di era modern. Hasil kajian literatur menunjukkan bahwa dalam mengembangkan sistem pendidikan menjadi institusi yang unggul dan untuk mempertahankan eksistensinya, madrasah di Islamic boarding school dituntut terbuka dan mengakomodasi aspirasi 
dan tuntutan masyarakat. Madrasah perlu mengembangkan diri agar menjadi madrasah yang bermutu dan unggul, serta menjadi jembatan yang menghubungkan dengan sistem pendidikan nasional, khususnya terkait dengan pengembangan moral dan kepribadian peserta didik. Hal ini bisa dimaklumi karena masyarakat berharap produk lembaga pendidikan di Islamic boarding school adalah ahli agama, bermoral dan memiliki keterampilan untuk masa depan.

Keywords: Islamic Boarding School, Madrasah, Policy, Superior Education.

Received: November 25, 2020; Revised: December 13, 2020; Accepted: December 27, 2020

\section{INTRODUCTION}

Islamic boarding schools are generally considered the basis of traditional Islam, namely Islamic educational institutions firmly bound by medieval scholars deeply rooted in classical Islamic Arabic culture (Hossain, 2019) because it is a conventional implementation learning model. Islamic boarding schools almost entirely follow traditions, both in their curriculum and in their learning methods. Even so, several Islamic boarding schools were still consistent in maintaining the salafiyah pattern, which they considered sophisticated in dealing with external problems. Whereas in reality, as religious and social educational institutions, Islamic boarding schools must do contextualization without sacrificing and abandoning their original character and face (Ismail Suardi Wekke, Siddin, 2017).

This can occur due to several factors, namely: (1) in terms of leadership, Islamic boarding school are still firmly managed with centralistic and hierarchical leadership centred on a kyai; (2) methodological crisis. In the field of methodology, the Islamic boarding school has a strong tradition in classical science transmission, so that the learning process uses teacher-oriented rather than student-oriented (Muhammad Asbar, 2018). Because due to the lack of methodological improvisation, the transmission process only gave birth to an accumulation of confusion. Knowledge concerned is considered something that is round and cannot be added. The transmission process is an acceptance that is taken for granted (Hadi, 2019), and (3) disorientation occurs. Namely, the Islamic boarding school loses its ability to define and position itself in the midst of rapidly changing social realities (Raikhan, 2015). In line with community life dynamics, Islamic boarding school have experienced changes and developments regarding the administration of education. Today, not a few Islamic boarding schools in Indonesia have adopted the government's formal education system. In general, formal education established in an Islamic boarding school is still in the path of Islamic education (madrasah). However, some Islamic boarding school already have educational institutions with a system of Elementary Schools, Junior High Schools, Senior High Schools, Vocational High Schools, and some have even opened universities (Syaiful, 2018);(Yuan, K., Aftoni, A., \& Çobanoğlu, 2020). The changes that occur in the Islamic boarding school show developments in adapting to the times' needs. However, all these changes did not uproot Islamic boarding school from their cultural roots. In general, Islamic boarding school still have institutional functions that transfer religious Knowledge (tafaqquh fi al-din), religious institutions that exercise social control, carry out social engineering while continuing the wetonan and sorogan systems (Janan Asifudin, 2017). All forms of changes in the development 
of the education system carried out by an Islamic boarding school are not without reason. The system's story is based on logic to maintain the old ways that are still good (al-muhafadzah 'ala al-qadim al-salih wa al-akhdh bi al-jadid al-aslah). These principles are the fundamental values and philosophies that underlie the Islamic boarding school's life to transform the potential and make themselves an agent of change for society (Suradi, 2017).

On the other hand, the high public expectations of Islamic boarding schools graduates impact the reform of the boarding school's management rapidly and require having a formal institution both affiliated with the Ministry of Religion and the Education Office. This also indicates that the community has begun to be "literate" and aware of formal education's urgency at this time. Society has already started to recognize that having practical abilities is not enough to give confidence that we can show our existence during existing competition. But how this existence is followed by formal legal will provide balanced implications between practical and academic recognition (Anwar, 2021). Thus, the Islamic boarding schools management system's change illustrates the reality of the Islamic boarding schools world that stands firmly on the foundation of traditions. However, on this basis, change can be managed in such a way by removing old elements and habits by incorporating new features according to community needs.

\section{METHOD}

This study was made by reviewing and collecting information from various references, books, articles, and journals used to study and conceptually add insights related to the opportunities and challenges of developing Islamic boarding schools based on a modern madrasah era. After collecting information and going through a series of literary studies and thought processes, all the theories, concepts, facts and information about the opportunities and challenges of developing Islamic boarding schools that are obtained are reviewed and then integrated into one scope of discussion which can answer the author's curiosity regarding the potential development towards reform of superior education models in the area of Islamic boarding school based madrasah.

\section{RESULT AND DISCUSSION}

\section{Result}

Madrasah is an example of a formal educational institution that focuses on spiritual or religious Knowledge and aspects of academic intelligence that emphasizes students' achievement in intellectual matters, leading to various educational measures. As a boarding school-based formal education institution, madrasah has also undergone curriculum changes. In its implementation, the madrasah curriculum also refers to the Education Office's curriculum and the Ministry of Religion. This is sufficient to reflect that madrasah is also at the forefront of implementing the National curriculum and creating scientific and religious graduates.

Islamic boarding schools have many advantages over other educational institutions because they originate from religious understanding and understanding of the kyai, then actualized as pious deeds. The dynamics of Islamic boarding school are increasingly adaptive to the times by organizing Islamic boarding school based 
madrasah, allowing Islamic boarding school to become Islamic educational institutions that will create whole people and form a civil society characterized by a religious, democratic, egalitarian, tolerant, just and knowledgeable community. The concept of the education model initiated in madrasah is a superior education concept that departs from a management process that is designed in such a way as to have a clear vision and mission and consistency of objectives, thus triggering a strategic environment that refers to the specified quality measures.

In line with the development of an increasingly advanced world, a society with an adequate rationality level, close to a proper level of rationality, is already intelligent enough to make more rational and forward-looking choices are no longer emotional and rely on primordialism. They choose educational institutions for their children who are very reasonable and consider future perspectives. They will make educational institutions choices that they see as ideal, namely educational institutions that can develop spiritual and moral potential, develop intellectual aspects, and create their students' social potential and skills. Departing from the perspective of human resource development, there are several trends that need to be considered in making superior madrasah in Islamic boarding schools, including: (1) education is increasingly required to appear as a key in developing the quality of human resources, namely humans who have insight, ability, skills and personality in accordance with the real needs faced by the people or nation; (2) in the perspective of the world of work, the orientation to natural abilities (what one can do) that can be displayed by education graduates will be more robust; (3) as a result of globalization, the quality of a community's education is not only measured based on their internal criteria, but compared to other community education; (4) the appreciation and expectations of the world of education are increasing, namely education that is of higher quality, relevance and accountability for the results; and (5) as a religious society, education is directed at cultivating Islamic character (piety, politeness, patience, courage, wisdom, etc.) in addition to providing other competences of academic nature and skills.

The superiority of human resources that Islamic boarding schools want to achieve through superior madrasah is the creation of a quality young generation not only in the cognitive aspects but also in the affective and psychomotor aspects so that the development of madrasah in the Islamic boarding school community in this direction will not only create interaction and scientific integration that more intense and more integrated, among others, religious and general sciences but also possess specific theoretical and practical capabilities that the global era needs. This idea begins with the intention and determination to realize madrasah as the only institutions capable of combining the strengths of science and technology and faith and piety. The leading madrasah in Islamic boarding schools is expected to produce human resources of $u l u$ al albab, which are described in the holy book Al-Qur'an, surah Ali Imron verses 190191.

In realizing madrasah to become excellent institutions, of course, a particular strategy is needed. This strategy reflects the thought that to achieve an organizational goal, a system must make it easier for the organization's actors to achieve the vision and mission that has been set. Therefore, several strategies need to be carried out by madrasah stakeholders to achieve this superior education: (1) making improvements and development management comprehensively and continuously so that the Islamic boarding school has a clear vision and mission in carrying out the existing education wheels. Reform in power from traditional government to conventional management by 
the demands and needs of the times; (2) building various strengths in a madrasah, such as creating high competence, dedication and commitment, having high achieving students, namely students born from a creative and effective learning process, developing learning resources that do not only lie to the teacher, having a strong madrasah culture, has a role model in the madrasah, has a high motivation to be able to compete and create close togetherness from various components in the madrasah community; (3) strengthening madrasah leadership and management. Leadership is to influence, encourage, mobilize, direct and empower all madrasah resources to achieve educational goals in madrasah.

Meanwhile, the management function is to plan, organize, implement, and control the development of madrasah by the vision, mission, goals and objectives, as well as future orientation; (4) to build an image, and there is an adage that all madrasah must hold, namely do a good job; do a good job; do a good job, and tell people about it; (5) developing special programs. The madrasah principal must observe and map the only programs that are being designed and produced by their competitors. This mapping is necessary so that it is not trapped in developing the same superior plan. The mapping can determine the choice of only programs by being different, being the first, being the best; and (6) Must have the courage to change the mindset or way of thinking of Muslims, to be more concerned with social interests and not fall into spiritual hedonism, namely worship experts who only provide benefits to themselves, not benefit others.

It is necessary to develop education in madrasah by implementing four strategies, namely: (1) substantive strategy, which educational institutions need to present comprehensive programs; (2) bottom-up approach, namely that educational institutions must grow and develop from below; (3) deregulatory strategy, namely educational institutions as far as possible not tied to standardized regulations that are too centralized and obeying, in the sense that it takes courage to develop educational institutions that are out of the box; and (4) a cooperative strategy, namely educational institutions need to create a network of cooperation, both with peer-to-peer educational institutions or with others at the regional, national and international levels.

\section{Discussion}

As public schools characterized by Islam, madrasah must always improve the quality of their human resources, both (faith and purity) and science and technology. The development of madrasah towards public schools with Islamic characteristics has been designed since the Minister of Religion offered the concept of madrasah development through the policy of a Joint Decree of 3 Ministers (Minister of Religion, Minister of Education, and Minister of Home Affairs), which seeks to align the quality of madrasah to those of public schools through a pattern curriculum, which is $70 \%$ consisting of general subjects and 30\% fields of religious studies. With the issuance of the Joint Ministerial Decree of 3 Ministers in 1975 concerning improving the quality of education in a madrasah, the public began to recognize madrasah's existence in the context of the national education system. Article 2 states: (1) a madrasah certificate has the same value as a general school diploma which is the same level; (2) madrasah graduates can continue to public schools at a higher level; and (3) madrasah students can transfer to public schools of the same level (Sudrajat, 2017). The problem is that most of the Indonesian Muslim community has responded to the Joint Decree to marginalize Islamic education, especially madrasah. This means they only understand 
it from a formal point of view. If the Substance Decree substance is understood correctly, this policy will significantly impact advancing the quality of madrasah education.

From time to time, an Islamic boarding school have grown and developed in quantity and quality. Not a few people pay attention and hope to Islamic boarding school as alternative education. Moreover, with various educational system innovations developed in Islamic boarding school by adopting a general education style, the Islamic boarding school is increasingly competitive in offering education to the public. Even though it has carried out various educational innovations until now, Islamic boarding school education has not lost the unique characteristics from the general education model formulated in a school (Ilyasin, 2020). Indeed, more and more Islamic boarding school are establishing madrasah. There are 2072 Islamic boarding schools with Madrasah Ibtidaiyah, 2721 Islamic boarding schools own the Madrasah Tsanawiyah, 1580 Islamic boarding schools acknowledge the Madrasah Aliyah, and the Madrasah Aliyah Keagamaan is owned by 176 Islamic boarding schools (Legistia, 2019).

However, the complexity of the problems and challenges is present. At least there are two, namely: first, challenges that come from outside and are commonly referred to as global challenges. In this context, madrasah must seize roles and keep up with the demands of the times. Second, the problems and challenges of educational autonomy. This demands quality human resources and a healthy and extensive source of funding. Of course, these challenges need to be responded to positively immediately. If they are not immediately responded to, gradually, the madrasah in Islamic boarding school will be left behind (Fadhilah Hasib, Iswati, Hartutik, \& Swasana Ramadhan, 2017). To overcome these problems, madrasah in Islamic boarding school must try to reactualize to increase the quantity and quality of graduates, achieve and gradually exceed the eight national education standards as in Government Regulation Number 19 of 2005, and develop unique programs that can improve the image of madrasah in society or government.

Therefore, it is only natural that the development of madrasah education in Islamic boarding school will strengthen the national education system's social character, which helps produce human resources with reliable mastery of Knowledge and technical skills who are always imbued with noble religious values. Islamic boarding school has become a centre of excellence for developing human resources that have a moral basis in social life. In the end, human resources born from madrasah in this Islamic boarding school can ideally and practically play an active role in every social change towards the realization of complete social life order. This is the advantage possessed by Islamic boarding school education. Madrasah is a formal Islamic-based educational organization system, namely social institutions, planned to achieve academic goals. Madrasah is a unique social system with a variety of different individual cultures integrated into one madrasah system. Therefore, madrasah will not be separated from the beliefs and values of the surrounding community. As a social system, Madrasah always maintains boundaries that separate and differentiate them from their environment (Priatmoko, 2018).

Witanti (2016) adds that the concept of superior madrasah departs from a management process that designs so that the consistency of vision and mission and character of goals and targets are implemented in work programs by accommodating a strategic 
plan environment referring to the determined quality measures. This concept cannot be separated from the idea of excellence, which provides a perspective for analyzing a useful superior madrasah model. This advantage can be measured by achieving targets as part of achieving a clear and consistent vision and mission of madrasah education with an orientation to quality improvement. Strictly speaking, a superior approach is carried out through management that is designed to lead to continuous quality improvement.

Thus the concept of superior education in madrasah can be interpreted as a form of the quality madrasah. Talking about quality can mean different things for everyone because quality has many criteria and depends on the context. Quality is a concept that continues to experience developments in its meaning. Priatmoko (2018) defines quality with full customer satisfaction. In this sense, a quality madrasah is an Islamic religion-based madrasah that can satisfy both internal and external customers (Musyarrofah, 2018). Education that focuses on quality will continue to develop programs and services that meet user needs, such as character and society. The community in question is broadly referred to as graduate users, namely the business world, educational institutions, government and the wider community, including creating their businesses by graduates. So that educational institution is said to have quality if they can meet the requirements demanded by users of educational services. If its performance exceeds the criteria required in stakeholders (users), then a new educational institution can be superior. Quality is determined by the standard specifications set and always adjusted to customer needs (Ihsan, 2018).

Quality education can be seen in terms of student achievement, the learning process, graduates' ability to develop their potential in society, and problem solving and critical thinking. Therefore, it is necessary to assess the quality in terms of process, product and internal aspects and suitability. The rate seen from the process is the effectiveness and efficiency of all factors that play a role in the education process, for example, the quality of teachers, school infrastructure, learning atmosphere, implemented curriculum, and madrasah management. Graduates from madrasah who have factors that support the high-quality learning process will have high Knowledge, skills and abilities (Bin-Tahir, Atmowardoyo, Dollah, \& Rinantanti, 2017). In terms of internal efficiency, superior and quality education is education whose institutional and curricular goals can be achieved.

In contrast, in terms of suitability, quality education is education whose graduates' abilities are by the workforce's needs and according to new student admissions criteria (Styaningsih, 2016). Associated with national goals, quality education based on Law Number 20 of 2003 concerning the National Education System Article 3 is quality education is capable of realizing the development of students' potential to become believers and devoted to God Almighty, with noble character. Healthy, knowledgeable, competent, creative, independent, democratic, and responsible.

Observing some of the above criteria, it can be seen that superior madrasah education must include students, facilities and infrastructure, madrasah environment, educators, curriculum, learning process, local content programs, and self-development even related to long coaching, meaning that madrasah must be able to fully develop the child, so a boarding house is needed. However, it needs to be proven by the high public interest in sending their children to the madrasah. This condition also indicates that it does not have an excellent value if the community does not ask a madrasah. In 
connection with the context of Islamic education in Indonesia, there are several additional criteria from superior madrasah, namely having the greatness of character and nobility, the creation of religious culture in a madrasah, integration between spiritual and general insights in the learning process, cognitive development, personality and spirituality of students in an integrative and comprehensive (Makmun, 2014).

Today, people's tastes and tendencies toward education are changing. Previously, madrasah was only required to produce graduates who were more proficient in religious Knowledge. People want madrasah to produce graduates who have comprehensive competences, master religious education (faith and purity) and general science. That many parents of students wish to doctors and scholars who are doctors, technocrats who are scholars or technical scholars, researchers who are clerics or scholars who are researchers, and other professions who have excellent religious mastery (Kurniawati, 2018).

In this context, madrasah have the opportunity to meet the demands of the community for several reasons, namely: (1) the occurrence of social mobility, namely the emergence of a new middle society, especially intellectuals who have recently experienced rapid development (Dasuki, 2019), the new middle class has a significant role in the process of social transformation which has implications for demands for educational facilities by their aspirations, both ideals and social status; (2) the emergence of a new awareness in religion (santrinisasi), especially in urban communities, upper-middle-class community groups, as a result of the re-Islamization process carried out intensively by religious organizations, da'wah institutions or carried out individually (Riyadi, 2014); and (3) the rapid flow of globalization and modernization needs to be addressed wisely. Modernization, with its impact, needs to be prepared by humans who have two competencies at once, namely science and technology and values of religious spirituality. The flow of globalization and modernization has implications for society's demands and expectations for education, which in addition to developing the academic potential of science and technology and the internalization of religious values (Suradi, 2017).

This condition demands changes to the madrasah in the Islamic boarding school, even in recent years. Emerging and developing asks the Indonesian Muslim community to build superior madrasah at various levels of education. The goal is clear, namely, to achieve excellence in religion and the field of general science (Kuntoro, 2019). Therefore, apart from preparing students to be smart in faith and have religious behaviour, madrasah in Islamic boarding school must also organize various resources that make students stylish in multiple sciences, technology, sports and arts. Of course, this change is not enough to change the curriculum, but also, the most important thing is to change the way all components think about the new madrasah paradigm. Changes in this method will then affect changes in the madrasah's various values, which will also affect the change in madrasah culture (Warti'ah, 2020). Judging from the internal demands and global external challenges, Islamic boarding schools must have mastery of science and technology and superior quality of human resources. Indonesia's development goals to create physically and mentally prosperous humans and Knowledge of science and technology require an ethical perspective and moral guidance. In turn, it will have an impact on increasing competitiveness and a high bargaining position in other areas of globalization (Rasyid, 2015). 


\section{CONCLUSION}

To develop the education system into a preeminent institution and maintain its existence, madrasah in Islamic boarding school are required to be open and accommodating to the community's aspirations and demands. Madrasah needs to develop themselves to become high quality and superior madrasah and become a bridge that connects with the national education system, especially regarding students' moral and personality development. This is understandable because the community hopes that educational institutions in Islamic boarding schools are religious experts, have honesty, and have skills for their future. Another factor that is no less important in realizing excellent madrasah in an Islamic boarding school is the Islamic values that are actualized integrally in the entire process of implementing education. These values are translated into madrasah management behaviour and build their commitment to realizing quality education. Therefore, the Islamic boarding school's habituation is very significant in cultivating awareness, both potential and cultural. Through this habituation, students are invited to understand education's reality by the development of science and technology. Given that Islamic boarding school is an ideal educational institution because it provides a laboratory for life skills (life skills), which are very useful for students' science and self-actualization.

\section{REFERENCES}

[1] Anwar, S. (2021). Internalisasi Nilai Pendidikan Akhlak dalam Surat Al-Hujurat Tafsir fi ZIlalil Qur'an. JIE: Journal of Islamic Edication, 6(1), 1-12.

[2] Bin-Tahir, S. Z., Atmowardoyo, H., Dollah, S., \& Rinantanti, Y. (2017). Multilingual learning program: pesantren students' perceptions of the multilingual simultaneous-sequential model. JELE (Journal of English Language and Education), 3(2), 44. https://doi.org/10.26486/jele.v3i2.292

[3] Dasuki, M. (2019). Pengembangan Kurikulum Pesantren As-Sunniyyah Kencong Jember. FALASIFA: Jurnal Studi Keislaman, 10(2), 29-49. https://doi.org/10.36835/falasifa.v10i2.195

[4] Fadhilah Hasib, F., Iswati, S., Hartutik, \& Swasana Ramadhan, D. (2017). Islamic Model of Corporate Governance at The Islamic Boarding School. Journal of Business and Economics Review, 2(1), 56-63.

[5] Hadi, A. (2019). Membangun Pengetahuan dan Kreativitas. Al-Risalah, 10(2), 128144. https://doi.org/10.34005/alrisalah.v10i2.408

[6] Hossain, D. M. (2019). A Literature Discourse on the Development of Islamisation of Knowledge Models: Strategising New Project Based Implementation Approach to Benefit Human Sciences. IIUM Journal of Human Sciences, 1(1), 43-56.

[7] Ihsan, M. (2018). Upaya Penguatan Pendidikan Agama Islam Berbasis Literasi $\begin{array}{lllll}\text { Pesantren. } & \text { LIBRARIA: Jurnal Perpustakaan, }\end{array}$ https://doi.org/10.21043/libraria.v6i1.3832

[8] Ilyasin, M. (2020). Transformation of Learning Management: Integrative Study of Islamic Boarding School Curriculum. Dinamika Ilmu, 20(1), 13-22. https://doi.org/10.21093/di.v20i1.2006 
[9] Ismail Suardi Wekke, Siddin, dan I. K. (2017). Pesantren, Madrasah, Sekolah, dan Panti Asuhan: Potret Lembaga Pendidikan Islam Minoritas Muslim. At-Tajdid: Jurnal Ilmu Tarbiyah, 6(1), 127-143.

[10] Janan Asifudin, A. (2017). Manajemen Pendidikan untuk Pondok Pesantren. MANAGERIA: Jurnal Manajemen Pendidikan Islam, 1(2), 355-366. https://doi.org/10.14421/manageria.2016.12-10

[11] Kuntoro, A. T. (2019). Manajemen Mutu Pendidikan Islam. Jurnal Kependidikan, 7(1), 84-97. https://doi.org/10.24090/jk.v7i1.2928

[12] Kurniawati, A. (2018). Pendidikan Karakter dengan Pendekatan Berbasis Agama dan Budaya Bangsa. Jurnal Ilmiah Pesantren, 4(2), 515-525.

[13] Legistia, Y. T. (2019). Strategy of Islamic Boarding School Based State Islamic Secondary School Development. https://doi.org/10.2991/icream-18.2019.87

[14] Makmun, H. A. R. (2014). Pembentukan Karakter Berbasis Pendidikan Pesantren : Cendikia, 12(2), 212-238.

[15] Muhammad Asbar, A. (2018). Implementasi Model Discovery Learning dalam Mata Pelajaran Pendidikan Agama Islam dan Budi Pekerti di SMAN 1 Bulukumba. SYAMIL: Jurnal Pendidikan Agama Islam (Journal of Islamic Education), 6(1). https://doi.org/10.21093/sy.v6i1.909

[16] Musyarrofah, M. (2018). Deradikalisasi Melalui Pendidikan Karakter Berbasis Khazanah Pesantren. Jurnal Mudarrisuna: Media Kajian Pendidikan Agama Islam, $8(1), 46-59$.

[17] Priatmoko, S. (2018). Implementasi Pendidikan Karakter Berbasis Pesantren di Madrasah. MIDA: Jurnal Pendidikan Dasar Islam, 1(1).

[18] Raikhan. (2015). Eksistensi Pendidikan Agama. Madinah: Jurnal Studi Islam, 2(1), $49-64-49-64$.

[19] Rasyid, M. R. (2015). Eksistensi Pesantren Dalam Sistem Pendidikan Nasional. AlRiwayah: Jurnal Kependidikan, 7(1), 127-139. https://doi.org/10.47945/alriwayah.v7i1.92

[20] Riyadi, A. (2014). Tarekat Sebagai Organisasi Tasawuf. Jurnal At-Taqaddum, 6(2), 359-385.

[21] Styaningsih, R. (2016). Kontinuitas Pesantren dan Madrasah di Indonesia. AT TA'DIB, 11(1). https://doi.org/10.21111/at-tadib.v11i1.651

[22] Sudrajat, A. (2017). Pesantren Sebagai Transformasi Pendidikan Islam di Indonesia. Vicratina: Jurnal Pendidikan Islam, 2(2), 64-88.

[23] Suradi, A. (2017). Transformasi Pondok Pesantren (Analisis Dampak Transformasi Sistem Pendidikan Terhadap Penanaman Panca Jiwa Pondok Pesantren Kepada Santri di Provinsi Bengkulu). TADRIS: Jurnal Pendidikan Islam, 12(2), 272-297.

[24] Syaiful, A. (2018). Politik Pendidikan Islam Masa Reformasi. AL-IMAN: Jurnal Keislaman Dan Kemasyarakatan, 2(1), 134-154.

[25] Warti'ah, W. (2020). The Implementation of Madrasa Culture in Building Students' Character. Nazhruna: Jurnal Pendidikan Islam, 3(2), 247-259. https://doi.org/10.31538/nzh.v3i2.583 
209 Al-hayat: Journal of Islamic Education (AJIE)

e-ISSN: 2599-3046 (online) | Volume 4, Issue 2 | December 2020

p-ISSN: $2657-1781$ (print)

[26] Witanti, F. N. (2016). Revitalisasi Madrasah Sebagai Lembaga Pendidikan Integratif- Alternatif. Tarbiyatuna, 7(1), 82-93.

[27] Yuan, K., Aftoni, A., \& Çobanoğlu, Ö. (2020). the Effect of Problem-Based Learning Model and Blended Learning Model To Metacognitive Awareness. Jurnal Pendidikan Teknologi Dan Kejuruan, 26(2), 183-188. https://doi.org/10.21831/jptk.v26i2.32783 